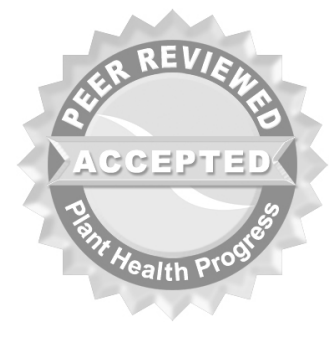

(c) 2004 Plant Management Network.

Accepted for publication 26 August 2004. Published 8 September 2004.

\title{
Managing Resistance of Venturia inaequalis to the Strobilurin Fungicides
}

William W. Turechek and Wolfram Köller, Cornell University, NYSAES, Department of Plant Pathology, Barton Laboratory, Geneva, NY 14456

Corresponding author: William W. Turechek.wwt3@cornell.edu

Turechek, W. W., and Köller, W. 2004. Managing resistance of Venturia inaequalis to the strobilurin fungicides. Online. Plant Health Progress doi: 10.1094/PHP-2004-0908-01-RS.

Abstract

Over the past thirty years, fungicide resistance has been cited as the cause of large-scale crop losses due to apple scab in a number of commercial orchards in the Northeast. The strobilurins represent the most recent class of fungicides for which the threat of resistance exists. In this article we examine the use of strobilurin fungicides at their highest and lowest labeled rates and as a mixture of the lowest labeled rate with a protectant fungicide in commercial spray programs for efficacy against apple scab as well as their utility in a resistance management program. Our results suggest that anti-resistance properties of high strobilurin rates are superior to low rates and low rate mixtures with a protectant fungicide.

\section{I ntroduction}

Apple growers consider the economy, efficacy, and (less often) the potential for the development of resistance when selecting fungicides for managing apple scab. Numerous apple growers have lost or are in danger of losing several classes of highly effective scab fungicides due to the development of resistance. These include dodine, the benzimidazoles (benlate and thiophanate-methyl), and, most recently, the class of demethylation-inhibiting (DMI) fungicides, including fenarimol (Rubigan E.C.), myclobutanil (Nova 40W), and triflumizole (Procure 50WS) (2). The DMI fungicides, although still effective in many orchards, are gradually losing their efficacy due to quantitative sensitivity shifts in populations of $\mathrm{V}$. inaequalis $(4,7)$. The strobilurin fungicides represent a more recent class of chemistry available to growers for management of apple scab, with trifloxystrobin (Flint 50WG) and kresoxim-methyl (Sovran 50WG) registered for current use in the U.S.

The strobilurins, also named Qo inhibitors or QoIs for short, were introduced in the mid-1990s. They exhibit efficacy against a broad-spectrum of fungal diseases, possess significant postinfective activity, and have a unique mode of action (1). Several pathogens have developed qualitative resistance to the strobilurins caused by a G143A mutation of the cytochrome b target site (1). This mechanism of resistance was first described for a laboratory mutant of $\mathrm{V}$. inaequalis $(6,10)$ and more recently for an apple orchard in Germany $(8)$, but similar mutants have, thus far, not been identified in the United States. Instead, gradual quantitative shifts of population sensitivities to strobilurins are being discovered (8). It was speculated that such initially quantitative population responses might facilitate the generation of immune G143A mutants (8). Consequently, slowing the speed of initially quantitative shifts might be expected to slow the emergence of qualitative resistance based on the generation and subsequent selection of immune target site mutants.

For the class of DMI fungicides with their quantitative pattern of resistance development (7), high rates of application continued to provide disease control of the least sensitive isolates, thus slowing the speed of their selection (5). A mixture of the protectant mancozeb with a DMI at a low rate failed to slow the speed of selection. Instead, control of DMI-resistant isolates was only provided by the mixing partner mancozeb. It was thus recommended to combine both resistance management strategies: High label rates of DMIs in order to slow the speed of resistance development in mixture with a protectant to provide additional control of resistant isolates (5). 


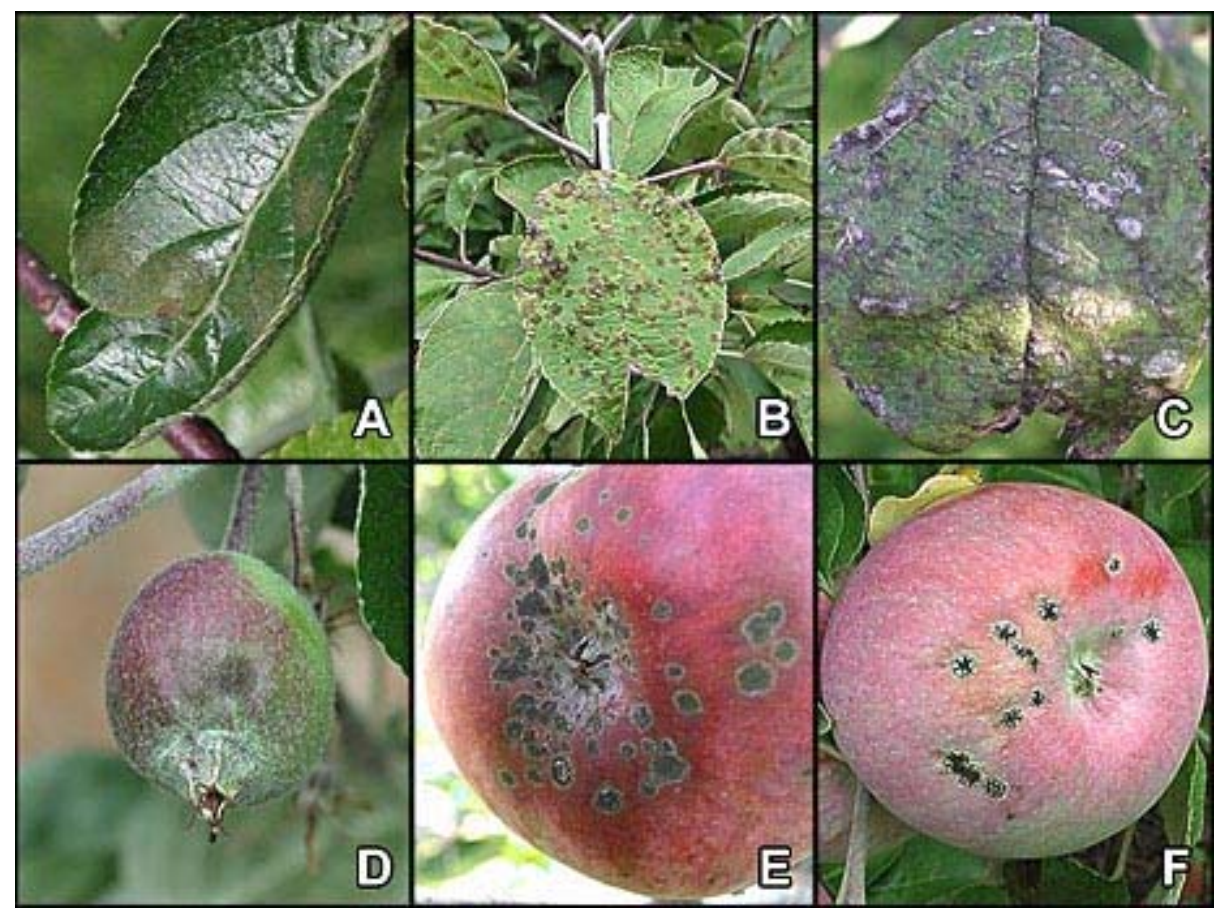

Fig. 1. A and B. Apple scab symptoms on (A) a cluster leaf and (B) a terminal leaf. C. Old or exhausted apple scab lesions on a terminal leaf. D. Young lesion on a developing fruit. $\mathbf{E}$ and $\mathbf{F}$. Well-developed lesions (E) on a mature fruit with characteristic cracking shown in $\mathrm{F}$.

The present study was designed to evaluate the utility of adding a protectant fungicide as a mixing partner with the strobilurin fungicides for: (i) improving control of apple scab; and (ii) managing fungicide resistance. The importance of recognizing the functional role of each mixing partner is emphasized.

\section{Efficacy Trials}

Trials were conducted in research orchards on the property of the New York State Agricultural Experiment Station in Geneva, NY. In 2002, trials were conducted in an orchard comprised of 27-year-old 'Cortland' trees planted on MM.106 rootstock. In 2003, trials were conducted in an orchard comprised of 28-year-old 'McIntosh' trees on MM.106 rootstock and in an 8-year-old orchard comprised of 'Empire' and 'J onagold' trees planted on MM.111 rootstock with an M.9 interstem. DMI-resistant isolates of Venturia inaequalis are prevalent in both the McIntosh and Cortland orchard blocks (8). The status of DMIresistance in the Empire orchard is unknown.

Single-tree plots, spaced $7.6 \mathrm{~m}$ apart within rows, were used in both the Cortland and McIntosh orchards. In the Empire/J onagold orchard, trees were planted in alternation within rows such that individual plots consisted of two trees, one 'Empire' and one 'J onagold'. In all orchards, treatments consisted of 4 replications arranged in a randomized complete block. Treatments began with one or two applications of mancozeb (Dithane RSNT) corresponding with the availability of mature ascospores and suitable climatic conditions. To comply with label restrictions, four strobilurin applications per season were integrated into a rotational scab management program, with the first application at tight cluster followed by applications at pink or early bloom, petal fall and ending with the first cover spray (Table 1). The strobilurins were applied: (i) singly at their highest labeled rates; (ii) singly at their lowest labeled rates; and (iii) as mixtures at their lowest labeled rates with mancozeb, also at the low label rate. All treatments were applied to drip using a handgun at a pressure of $2414 \mathrm{kPa}$. Additional cover sprays of Captan and thiophanate-methyl (Topsin-M) were applied with an airblast sprayer at a volume of water approximately one-third of that necessary for drip. 
Table 1. Fungicide application timings for three efficacy trials conducted in experimental orchards at the NY State Agricultural Experiment Station. Asterisks denote application dates that included a strobilurin fungicide.

\begin{tabular}{|c|c|c|c|}
\hline \multirow{2}{*}{$\begin{array}{l}\text { Apple } \\
\text { growth stage }\end{array}$} & \multicolumn{3}{|c|}{ Variety and year of experiment } \\
\hline & Cortland 2002 & McI ntosh 2003 & Empire 2003 \\
\hline Green tip & -- & April 16 & April 16 \\
\hline Half-inch green & April 18 & April 24 & April 24 \\
\hline Tight cluster & April 24* & April 30* & April 30* \\
\hline Pink & May 1 & May 7* & May 7* \\
\hline Bloom & May 8*, 15 & May 15 & May 15 \\
\hline Petal fall & May $21^{*}$ & May 22* & May $22 *$ \\
\hline First cover & May 29* & May 29* & May $29 *$ \\
\hline Second cover & June 13 & June 10 & June 10 \\
\hline Third cover & June 26 & June 23 & June 23 \\
\hline Fourth cover & July 11 & July 8 & July 8 \\
\hline Fifth cover & July 25 & July 16 & July 16 \\
\hline Sixth Cover & August 7 & July 23 & July 25 \\
\hline Seventh Cover & -- & August 8 & August 8 \\
\hline
\end{tabular}

Table 2. Fungicide performance in the management of apple scab in 2002 on 'Cortland' in an experimental orchard in Geneva, New York.

\begin{tabular}{|c|c|c|c|c|c|}
\hline \multirow[b]{2}{*}{ Fungicide } & \multirow[b]{2}{*}{$\begin{array}{c}\text { Rate }^{\text {w }} \\
\text { (g a.i./ha) }\end{array}$} & \multicolumn{2}{|c|}{ Terminal leaves } & \multicolumn{2}{|c|}{ Fruit scab } \\
\hline & & Incidence $^{x}$ & $\begin{array}{c}\text { Control } \\
(\%)^{\mathrm{y}}\end{array}$ & Incidence & $\begin{array}{c}\text { Control } \\
(\%)\end{array}$ \\
\hline Kresoxim methyl & 220 & $16.5 \mathrm{~cd}$ & 79.0 & $2.0 \mathrm{de}$ & 97.8 \\
\hline Kresoxim methyl & 140 & $18.5 \mathrm{~cd}$ & 76.4 & $3.7 \mathrm{de}$ & 96.0 \\
\hline $\begin{array}{l}\text { Kresoxim methyl } \\
+ \text { mancozeb }\end{array}$ & $\begin{array}{r}140 \\
2500\end{array}$ & $14.7 \mathrm{~d}$ & $\begin{array}{c}81.3 \\
(87.2)^{z}\end{array}$ & $0.5 \mathrm{e}$ & $\begin{array}{c}99.5 \\
(99.2)\end{array}$ \\
\hline Trifloxystrobin & 105 & $16.0 \mathrm{~cd}$ & 79.6 & $3.7 \mathrm{de}$ & 96.0 \\
\hline Trifloxystrobin & 70 & $15.2 \mathrm{~cd}$ & 80.6 & $5.0 \mathrm{de}$ & 94.6 \\
\hline $\begin{array}{l}\text { Trifloxystrobin } \\
+ \text { mancozeb }\end{array}$ & $\begin{array}{r}70 \\
2500\end{array}$ & $22.5 \mathrm{~cd}$ & $\begin{array}{c}71.3 \\
(89.4)\end{array}$ & $6.2 \mathrm{~cd}$ & $\begin{array}{c}93.3 \\
(99.0)\end{array}$ \\
\hline Mancozeb & 2500 & $42.7 b$ & 45.6 & $17.7 \mathrm{bc}$ & 80.9 \\
\hline Myclobutanil & 126 & $26.7 \mathrm{c}$ & 66.0 & $21.8 \mathrm{~b}$ & 76.5 \\
\hline UTC & -- & $78.5 \mathrm{a}$ & -- & $92.9 \mathrm{a}$ & -- \\
\hline
\end{tabular}

${ }^{\mathrm{w}}$ Rate is based on 2800 liter/ha.

$x$ Mean percent disease values from four replicate plots per treatment from disease ratings on August 16, 2002. Means within a column not followed by a common letter are significantly different from each other according to the pairwise difference option (PDIFF) in PROC MIXED ( $P<0.05)$.

$y$ Percentages of control were calculated as: 100 - incidence (treated) / incidence (untreated).

${ }^{\mathrm{z}}$ Expected additive effects (Expected $=A+B-[A B / 100]$ ). 
Table 3. Fungicide performance in the management of apple scab in 2003 on

'Mclntosh' in an experimental orchard in Geneva, New York.

\begin{tabular}{|c|c|c|c|c|c|}
\hline \multirow[b]{2}{*}{ Fungicide } & \multirow[b]{2}{*}{$\begin{array}{c}\text { Rate }^{\text {W }} \\
\text { (g a.i./ha) }\end{array}$} & \multicolumn{2}{|c|}{ Terminal leaves } & \multicolumn{2}{|c|}{ Fruit scab } \\
\hline & & Incidence ${ }^{x}$ & $\begin{array}{c}\text { Control } \\
(\%)^{\mathrm{y}}\end{array}$ & Incidence & $\begin{array}{c}\text { Control } \\
(\%)\end{array}$ \\
\hline Kresoxim methyl & 220 & $8.0 \mathrm{~d}$ & 89.8 & $7.8 \mathrm{e}$ & 91.8 \\
\hline Kresoxim methyl & 140 & $13.8 \mathrm{~d}$ & 82.4 & $13.0 \mathrm{de}$ & 86.3 \\
\hline $\begin{array}{l}\text { Kresoxim methyl } \\
+ \text { mancozeb }\end{array}$ & $\begin{array}{r}140 \\
2500\end{array}$ & $15.5 \mathrm{~d}$ & $\begin{array}{c}80.3 \\
(92.7)^{z}\end{array}$ & $6.8 \mathrm{e}$ & $\begin{array}{c}92.8 \\
(93.7)\end{array}$ \\
\hline Trifloxystrobin & 105 & $4.8 \mathrm{c}$ & 93.9 & $9.5 \mathrm{de}$ & 90.0 \\
\hline Trifloxystrobin & 70 & $13.5 \mathrm{~d}$ & 82.8 & $17.8 \mathrm{de}$ & 81.3 \\
\hline $\begin{array}{l}\text { Trifloxystrobin } \\
+ \text { mancozeb }\end{array}$ & $\begin{array}{r}70 \\
2500\end{array}$ & $14.8 \mathrm{~d}$ & $\begin{array}{l}81.1 \\
(92.9)\end{array}$ & $12.0 \mathrm{de}$ & $\begin{array}{c}87.4 \\
(91.4)\end{array}$ \\
\hline Mancozeb & 2500 & $32.5 \mathrm{bc}$ & 58.6 & $43.8 b c$ & 53.9 \\
\hline Myclobutanil & 126 & $36.5 \mathrm{~b}$ & 53.5 & $57.0 \mathrm{~b}$ & 40.0 \\
\hline UTC & -- & $78.5 \mathrm{a}$ & -- & $95.0 \mathrm{a}$ & -- \\
\hline
\end{tabular}

${ }^{\mathrm{w}}$ Rate is based on 2800 liter/ha.

$x$ Mean percent disease values from four replicate plots per treatment from disease ratings on August 18, 2003. Means within a column not followed by a common letter are significantly different from each other according to the pairwise difference option (PDIFF) in PROC MIXED ( $P<0.05)$.

$y$ Percentages of control were calculated as: 100 - incidence (treated) / incidence (untreated).

${ }^{\mathrm{z}}$ Expected additive effects (Expected $=A+B-[A B / 100]$ ).

Table 4. Fungicide performance in the management of apple scab in 2003 on 'Empire' in an experimental orchard in Geneva, New York.

\begin{tabular}{|c|c|c|c|c|c|}
\hline \multirow[b]{2}{*}{ Fungicide } & \multirow[b]{2}{*}{$\begin{array}{c}\text { Ratew }^{\text {wate }} \\
\text { (g a.i./ha) }\end{array}$} & \multicolumn{2}{|c|}{ Terminal leaves } & \multicolumn{2}{|c|}{ Fruit scab } \\
\hline & & Incidence $^{x}$ & $\begin{array}{c}\text { Control } \\
(\%)^{y}\end{array}$ & I ncidence & $\begin{array}{c}\text { Control } \\
(\%)\end{array}$ \\
\hline Kresoxim methyl & 220 & $1.5 \mathrm{c}$ & 97.7 & $0.5 \mathrm{~b}$ & 99.4 \\
\hline Kresoxim methyl & 140 & $1.3 \mathrm{c}$ & 98.0 & $3.0 \mathrm{~b}$ & 96.1 \\
\hline $\begin{array}{l}\text { Kresoxim methyl } \\
+ \text { mancozeb }\end{array}$ & $\begin{array}{r}140 \\
2500\end{array}$ & $0.8 \mathrm{c}$ & $\begin{array}{c}98.8 \\
(99.8)^{z}\end{array}$ & $1.5 \mathrm{~b}$ & $\begin{array}{c}98.1 \\
(99.7)\end{array}$ \\
\hline Trifloxystrobin & 105 & $1.3 \mathrm{c}$ & 98.0 & $1.0 \mathrm{~b}$ & 98.7 \\
\hline Trifloxystrobin & 70 & $0.8 \mathrm{c}$ & 98.8 & $4.5 \mathrm{~b}$ & 94.2 \\
\hline $\begin{array}{l}\text { Trifloxystrobin } \\
+ \text { mancozeb }\end{array}$ & $\begin{array}{r}70 \\
2500 \\
\end{array}$ & $1.5 \mathrm{c}$ & $\begin{array}{c}97.7 \\
(99.9)\end{array}$ & $0.5 \mathrm{~b}$ & $\begin{array}{c}99.4 \\
(99.5)\end{array}$ \\
\hline Mancozeb & 2500 & $7.0 \mathrm{~b}$ & 89.1 & $6.0 \mathrm{~b}$ & 92.3 \\
\hline Myclobutanil & 126 & $9.8 \mathrm{~b}$ & 84.8 & $12.5 \mathrm{~b}$ & 83.9 \\
\hline UTC & -- & $64.3 \mathrm{a}$ & -- & $77.5 \mathrm{a}$ & -- \\
\hline
\end{tabular}

${ }^{\mathrm{w}}$ Rate is based on 2800 liter/ha.

$x$ Mean percent disease values from four replicate plots per treatment from disease ratings on August 20, 2003. Means within a column not followed by a common letter are significantly different from each other according to the pairwise difference option (PDIFF) in PROC MIXED ( $P<0.05)$.

$y$ Percentages of control were calculated as: 100 - incidence (treated) / incidence (untreated).

${ }^{\mathrm{z}}$ Expected additive effects (Expected $=A+B-[A B / 100]$ ). 
Apple scab incidence (presence/ absence) was evaluated by examining all leaves on the 10 oldest fully expanded leaves on each of 10 terminal branches, and on 50 or 100 fruit per tree on the dates indicated in Tables 2, 3, and 4. Data were transformed using the arcsin transformation. Transformed data were analyzed by ANOVA using SAS PROC MIXED and treatment means were separated using the pairwise difference option (PDIFF) in PROC MIXED ( $\mathrm{P}<$ 0.05).

Results further document the efficacy of the strobilurin fungicides for managing apple scab under heavy disease pressure. Moreover, stobilurins remain highly effective in the management of DMI-resistant orchard populations of $\mathrm{V}$. inaequalis, as exemplified by the Cortland and McIntosh blocks reported previously as DMI-resistant (Tables 2 and 3) (8). Although not tested directly, the V. inaequalis population at the Empire block appears to be DMI-resistant, as indicated by the failure of myclobutanil to improve scab control above the level achieved with the protectant mancozeb alone (Table 4). In general, disease management was more effective in the Empire orchard (Table 4) versus the Cortland and McIntosh orchards (Tables 2 and 3), because the trees were younger and smaller (being grafted on to a dwarfing rootstock), consequently, spray coverage was more thorough. Additionally, disease pressure was perhaps lower because the orchard had not been subjected to the same degree of intentional inoculum build-up as the McIntosh and Cortland blocks.

In all three trials, the performance of both strobilurins was numerically improved at high application rates (Tables 2, 3, and 4). The same improvement was achieved by mixing strobilurins at their low rates with mancozeb (Tables 2 , 3 , and 4). However, the level of control achieved was consistently lower than expected from the purely additive effects of the mixture components, as calculated by Additive Effects $=A+B-(A B / 100)$, with $A$ and $B$ as the percentage of control achieved with each of the mixture components alone (9). A reason for the slightly antagonistic action of mancozeb in mixture with trifloxystrobin remains unclear.

\section{Sensitivity Shifts}

As reported recently, quantitative responses of the $\mathrm{V}$. inaequalis population to strobilurin treatments were documented in 2002 for the Cortland block, although respective sensitivity shifts had no apparent effect on strobilurin performance (8). In 2003, respective sensitivity shifts were evaluated for the McIntosh block (adjacent to the Cortland block) employing the same test procedure described previously (8). In brief, individual scab lesions were excised, and conidia were dispensed in water and allowed to germinate and develop mycelia for seven days on potato dextrose agar without fungicide or amended with $0.02 \mu \mathrm{g}$ a.i./ $\mathrm{ml}$ of the strobilurin trifloxystrobin. Sensitivities were measured as relative growth (RG) of mycelia (growth amended/growth unamended $\times 100$ ).

The results were consistent with data reported for 2002 (8). In comparison to a composite baseline population collected from five orchards never treated with any fungicide, the relative frequency of isolates at the McIntosh block had shifted significantly $(P<0.001)$ towards decreased trifloxystrobin sensitivity (Fig. 1). As documented previously (8), however, this magnitude of sensitivity shifts had no apparent impact on satisfactory scab performances of strobilurins (Table 3). 


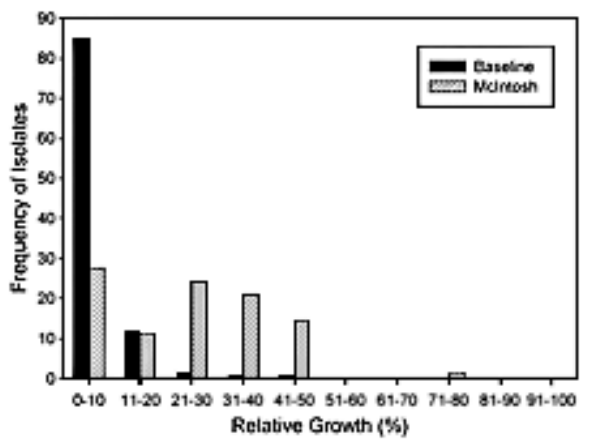

Fig. 2. Frequency distribution of trifloxystrobin sensitivities of Venturia inaequalis isolates for a composite baseline population never treated with trifloxystrobin (solid bars; $n=195$; mean relative growth $=3.2$ ) and for the population at an experimental Mclntosh orchard (hatched bars; $n=62$; mean relative growth $=23.1$ ). Mean relative growth $(R G)=$ growth amended/growth unamended $\times 100$ at a discriminatory dose of $0.02 \mu \mathrm{g} / \mathrm{ml}$ trifloxystrobin.

In order to assess the population response to treatments with the low and high rates of trifloxystrobin and the trifloxystrobin:mancozeb mixture, diseased leaves in the McIntosh block were collected from non-treated check-trees, and from trees treated with trifloxystrobin. In order to allow full population responses to season-long trifloxystrobin programs, diseased leaves were sampled two weeks after the last trifloxystrobin application. All three treatments with trifloxystrobin had highly significant effects on the mean RG values and the frequency distributions of isolate sensitivities (Table 5), indicating significant population responses to trifloxystrobin. Among the three treatment options, differences were not highly significant $(P>0.05)$. Isolates exhibiting $R G$ values $>50$ had been selected most prominently, with the mixture of trifloxystrobin and mancozeb mandating the lowest increase in frequencies (Table 5). Highly resistant isolates indicative of target site mutants were not identified in any of the populations tested, indicating that all population responses were quantitative in character.

Table 5. Responses of Venturia inaeaqualis populations to treatments with trifloxystrobin in 2003 ('Mclntosh').

\begin{tabular}{|l|c|c|c|c|c|c|}
\hline \multirow{2}{*}{ Fungicide } & \multirow{2}{*}{$\begin{array}{c}\text { Rate }^{\mathrm{w}} \\
\text { (g a.i./ha) }\end{array}$} & \multicolumn{3}{c|}{$\begin{array}{c}\text { Population } \\
\text { sensitivities }\end{array}$} & \multicolumn{2}{c|}{$\begin{array}{c}\text { I solate } \\
\text { frequencies (\% ) }\end{array}$} \\
\cline { 3 - 8 } & $\mathbf{n}$ & $\mathbf{R G}^{\mathrm{x}}$ & $\mathbf{P m}^{\mathrm{y}}$ & $\mathbf{R G}>\mathbf{5 0}$ & $\mathbf{P}^{\mathrm{z}}$ \\
\hline UTC & -- & 62 & 23.0 & & 1.6 & \\
\hline Trifloxystrobin & 70 & 40 & 38.2 & $<0.001$ & 17.5 & 0.003 \\
\hline Trifloxystrobin & 105 & 49 & 32.8 & 0.003 & 10.2 & 0.04 \\
\hline $\begin{array}{l}\text { Trifloxystrobin } \\
+ \text { mancozeb }\end{array}$ & $\begin{array}{r}70 \\
2500\end{array}$ & 51 & 32.0 & 0.002 & 7.8 & 0.1 \\
\hline
\end{tabular}

${ }^{w}$ Rate is based on 2800 liter/ha.

$x$ Mean relative growth ( $R G$ ) of mycelia (growth amended/growth unamended $x$ 100) at a discriminatory dose of $0.02 \mu \mathrm{g} / \mathrm{ml}$ trifloxystrobin.

$\mathrm{y}$ Comparison of mean RG values ( $t$ test).

${ }^{\mathrm{z}}$ Comparison of isolate frequencies exhibiting RG values $>50$ (log-linear analysis). 
The quantitative population responses to trifloxystrobin were determined by calculating the levels of scab control achieved for infections caused by the two subpopulations of V. inaequalis exhibiting RG values $\leq 50$ and $>50$. The proportion of disease caused by isolates belonging to the two subpopulations were calculated from the total disease incidence (Table 3) and the frequencies of isolates exhibiting RG > 50 (Table 5), according to a procedure employed previously (5).

The subpopulation of isolates with RG values $>50$ were not controlled at the low rate of trifloxystrobin, while the level of control achieved for sensitive isolates with RG $\leq 50$ was high for both fruit and leaf scab (Table 6). In contrast, trifloxystrobin at a high dose continued to provide measurable control of isolates with $\mathrm{RG}$ values > 50 (Table 6). The subpopulation exhibiting RG values > 50 was also less effectively controlled by the mixture of trifloxystrobin at the low rate with mancozeb and the control achieved with the mixture was considerably lower than the level expected from additive effects of the two fungicides in mixture (Table 6).

Table 6. Differential control of Venturia inaequalis isolates with different sensitivities to trifloxystrobin ('Mcl ntosh,' 2003).

\begin{tabular}{|l|c|c|c|}
\hline \multirow{2}{*}{ Fungicide } & \multirow{2}{*}{$\begin{array}{c}\text { Rate }^{\mathrm{w}} \\
\text { (g a.i./ha) }\end{array}$} & RG $^{\mathrm{y}} \leq \mathbf{5 0}$ & RG $>\mathbf{5 0}^{\text {Terminal leaf scab incidence }}$ \\
\cline { 3 - 5 } & -- & 77.2 & 1.3 \\
\hline Untreated check & 70 & $11.1[86]$ & $2.4[0]$ \\
\hline Trifloxystrobin & 105 & $4.3[94]$ & $0.5[62]$ \\
\hline Trifloxystrobin & 70 & $13.7[82]$ & $1.1[15]$ \\
\hline $\begin{array}{l}\text { Trifloxystrobin } \\
\text { + mancozeb }\end{array}$ & 2500 & {$[94]^{\mathrm{z}}$} & {$[59]^{\mathrm{z}}$} \\
\hline
\end{tabular}

$\mathrm{x}$ Rate is based on 2800 liter/ha.

$x$ Disease incidences caused by isolates displaying respective RG values were calculated from values given in Table 3. Numbers in parentheses reflect the percentage of control.

$y$ Mean relative growth (RG) of mycelia (growth amended/growth unamended $x$ 100) at a discriminatory dose of $0.02 \mu \mathrm{g} / \mathrm{ml}$ trifloxystrobin.

${ }^{z}$ Expected additive effect (Expected $=A+B-[A B / 100]$ ) calculated from the mancozeb performance data listed in Table 3.

\section{Conclusion}

The results presented in this study have impact on the management of $\mathrm{V}$. inaequalis resistance to strobilurins. In general, the pathway of resistance can be a qualitative selection of immune subpopulations, as exemplified by resistance to the benzimidazoles, or a quantitative and gradual response of populations as is most thoroughly documented for the DMI fungicides (3). In the latter case of quantitative resistance, control of resistant isolates remains dependent on the fungicide dose, allowing a decrease in the speed of resistance development at high doses (5). For the strobilurins, the path of resistance development was shown to follow a dual path, with a quantitative population response of $\mathrm{V}$. inaequalis populations followed by the selection of immune G143A target site mutants (8). Circumstantial evidence allowed speculation that (i) quantitative resistance as such can lead to unsatisfactory control of scab, and that (ii) slowing the speed of initially quantitative population responses might slow the subsequent phase of qualitative resistance development (8).

As for the DMIs with their quantitative development of resistance (5), our preliminary data indicate that a higher application rate of strobilurins will continue to provide control of isolates capable of escaping control at the lowest recommended rate, i.e., isolates with RG values > 50 (Table 6). High application rates can thus be expected to slow the speed of initially quantitative population responses toward strobilurin resistance. A mixture of trifloxystrobin at its lowest labeled rate with the protectant mancozeb also provided improved control of the 
subpopulation escaping from trifloxystrobin alone. However, the level of control was below the expected level of control achieved with mancozeb alone (Table 6). This slight antagonistic effect might diminish the effectiveness of the mixture in slowing the build-up of strobilurin-resistant subpopulations. Our results suggest that anti-resistance properties of high strobilurin rates are superior to low rate mixtures with mancozeb.

\section{Literature Cited}

1. Bartlett, D. W., Clough, J . M., Godwin, J . R., Hall, A. A., Hamer, M., and ParrDobrzanski, B. 2002. The strobilurin fungicides. Pest Manage. Sci. 58:649-662.

2. Gilpatrick, J. D. 1982. Case-study 2: Venturia on pome fruits and Monilinia on stone fruits. Pages 195-206 in: Fungicide Resistance in Crop Protection. J . Dekker and S. G. Georgopoulos, eds. Centre Agric. Publishing and Documentation, Wageningen, Netherlands.

3. Köller, W. 2001. Fungicide resistance. Pages 483-488 in: Encyclopedia of Plant Pathology. O. C. Maloy and T. D. Murray, eds. J ohn Wiley, New York.

4. Köller, W., and Wilcox, W. F. 2001. Evidence for the predisposition of fungicideresistant isolates of Venturia inaequalis to a preferential selection for resistance to other fungicides. Phytopathology 91:776-781.

5. Köller, W., and Wilcox, W. F. 1999. Evaluation of tactics for managing resistance of Venturia inaequalis to sterol demethylation inhibitors. Plant Dis. 83:857-863.

6. Köller, W., Avila-Adame, C., Olaya, G., and Zheng, D. 2001. Resistance to strobilurin fungicides. Pages 215-229 in: Agrochemical Resistance: Extent, Mechanism, and Detection. J . M. Clark and I. Yamaguchi, eds. Am. Chem. Soc., Washington, DC.

7. Köller, W., Wilcox, W. F., Barnard, J., Jones, A. L., and Braun, P. G. 1997. Detection and quantification of resistance of Venturia inaequalis populations to sterol demethylation inhibitors. Phytopathology 87:184-190.

8. Köller, W., Parker, D. M., Turechek, W. W., Avila-Adame, C., and Cronshaw, K. 2004. A tow-phase resistance response of Venturia inaequalis populations to the QoI fungicide kresoxim-methyl and trifloxystrobin. Plant Dis. 88:537-544.

9. Richter, D. L. 1987. Synergism: A patent point of view. Pestic. Sci. 19:309-315.

10. Zheng, D., Olaya, G., and Köller, W. 2000. Characterization of laboratory mutants of Venturia inaequalis resistant to the strobilurin-related fungicide kresoximmethyl. Curr. Genet. 38:148-155. 